\title{
The national and local politics of climate change adaptation in Zimbabwe
}

DOI:

https://doi.org/10.1080/17565529.2014.934777

\section{Document Version}

Final published version

Link to publication record in Manchester Research Explorer

\section{Citation for published version (APA):}

Mitlin, D., \& Dodman, D. (2014). The national and local politics of climate change adaptation in Zimbabwe. Climate and Development, 7(3), 223-234. https://doi.org/10.1080/17565529.2014.934777

\section{Published in:}

Climate and Development

\section{Citing this paper}

Please note that where the full-text provided on Manchester Research Explorer is the Author Accepted Manuscript or Proof version this may differ from the final Published version. If citing, it is advised that you check and use the publisher's definitive version.

\section{General rights}

Copyright and moral rights for the publications made accessible in the Research Explorer are retained by the authors and/or other copyright owners and it is a condition of accessing publications that users recognise and abide by the legal requirements associated with these rights.

\section{Takedown policy}

If you believe that this document breaches copyright please refer to the University of Manchester's Takedown Procedures [http://man.ac.uk/04Y6Bo] or contact uml.scholarlycommunications@manchester.ac.uk providing relevant details, so we can investigate your claim.

\section{OPEN ACCESS}


This article was downloaded by: [86.182.113.179]

On: 30 May 2015, At: 05:51

Publisher: Taylor \& Francis

Informa Ltd Registered in England and Wales Registered Number: 1072954 Registered office: Mortimer House, 37-41 Mortimer Street, London W1T 3J H, UK

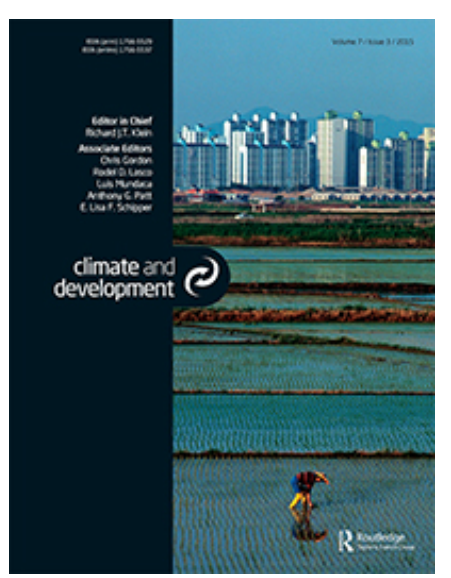

CrossMark

Click for updates

\section{Climate and Development}

Publication details, including instructions for authors and subscription information: http:// www. tandfonline.com/loi/tcld20

\section{The national and local politics of climate change adaptation in Zimbabwe}

\author{
David Dodman ${ }^{a} \&$ Diana Mitlin ${ }^{b}$ \\ a International Institute for Environment and Development (IIED), 80-86 Gray's Inn Road, \\ London WC1X 8NH, UK \\ ${ }^{\mathrm{b}}$ School of Environment, Education and Development, University of Manchester, Oxford \\ Road, Manchester M13 9PL, UK \\ Published online: $24 \mathrm{~J}$ ul 2014.
}

To cite this article: David Dodman \& Diana Mitlin (2015) The national and local politics of climate change adaptation in Zimbabwe, Climate and Development, 7:3, 223-234, DOI: 10.1080/17565529.2014.934777

To link to this article: http:// dx. doi.org/ 10.1080/17565529.2014.934777

\section{PLEASE SCROLL DOWN FOR ARTICLE}

Taylor \& Francis makes every effort to ensure the accuracy of all the information (the "Content") contained in the publications on our platform. Taylor \& Francis, our agents, and our licensors make no representations or warranties whatsoever as to the accuracy, completeness, or suitability for any purpose of the Content. Versions of published Taylor \& Francis and Routledge Open articles and Taylor \& Francis and Routledge Open Select articles posted to institutional or subject repositories or any other third-party website are without warranty from Taylor \& Francis of any kind, either expressed or implied, including, but not limited to, warranties of merchantability, fitness for a particular purpose, or non-infringement. Any opinions and views expressed in this article are the opinions and views of the authors, and are not the views of or endorsed by Taylor \& Francis. The accuracy of the Content should not be relied upon and should be independently verified with primary sources of information. Taylor \& Francis shall not be liable for any losses, actions, claims, proceedings, demands, costs, expenses, damages, and other liabilities whatsoever or howsoever caused arising directly or indirectly in connection with, in relation to or arising out of the use of the Content.

This article may be used for research, teaching, and private study purposes. Terms \& Conditions of access and use can be found at http://www.tandfonline.com/page/terms-and-conditions

It is essential that you check the license status of any given Open and Open Select article to confirm conditions of access and use. 


\title{
RESEARCH ARTICLE
}

\section{The national and local politics of climate change adaptation in Zimbabwe}

\author{
David Dodman $^{\text {a* }}$ and Diana Mitlin ${ }^{\mathrm{b}}$ \\ ${ }^{a}$ International Institute for Environment and Development (IIED), 80-86 Gray's Inn Road, London WC1X 8NH, UK; ${ }^{b}$ School of \\ Environment, Education and Development, University of Manchester, Oxford Road, Manchester M13 9PL, UK
}

(Received 16 November 2013; final version received 8 April 2014)

\begin{abstract}
The description and analysis of climate change adaptation programmes in low- and middle-income countries rarely examines the political conditions and contexts in which these take place, or the way in which these activities may themselves shape local and national politics. This paper uses a case study of Zimbabwe to examine how the discourse and practice of climate change has been incorporated in, and has the potential to influence, national politics in a context marked by high levels of contestation. It identifies the ways in which climate change is framed within national political discourses, and describes the structures for governing climate change adaptation and how these are influenced by global priorities and policies. The paper then raises specific questions that are fundamental to understanding the broader political implications of work related to climate change in low-income countries, and argues that these must be engaged with if climate change adaptation is to generate sustainable long-term improvements in livelihoods and well-being for citizens in these contexts.
\end{abstract}

Keywords: politics; governance; transformation; climate change; Zimbabwe

\section{Introduction}

A growing number of research papers, books, blogs, and other articles refer to the "politics of climate change" as one of the key elements shaping current and future responses to this global challenge. This is usually presented as an issue of global politics (related to the contested negotiations of the United Nations Framework Convention on Climate Change (UNFCCC)), as national politics in highincome countries (for example, the tension between the Obama White House and the US Congress over climate change legislation), or in the role of global corporate actors in the international politics and economy of climate change (Tanner \& Allouche, 2011). Similarly, the framing of climate change in major international development publications such as the United Nations Development Programme's (UNDP) Human Development Report and the World Bank's World Development Report focuses on issues such as the attribution of responsibilities at a global level, the need for market-based mechanisms to reduce emissions and to reduce risk, and the global politics involved in responding to these issues (Gasper, Portocarrero, \& St.Clair, 2013) - but rarely recognize the political dimensions of engaging with these issues at the national level (particularly in low- and middle-income nations). Although the governance of climate change in the urban context has received substantial attention (Betsill \& Bulkeley, 2006; Birkmann, Garschagen, Kraas, \& Quang, 2010; Bulkeley \& Betsill, 2005; Kehew et al., 2013; Roberts, 2008, 2010; Tanner, Mitchell, Polack, \& Guenther, 2009), this literature has tended to focus on legal and institutional frameworks and decision-making processes.

In contrast, the national and local politics of climate change adaptation in low- and middle-income countries and cities are under-explored (Lockwood, 2013), with much more focus being placed on technical solutions to support adaptation (whether these are community-based, planning-based, or technological). However, the growing scale of climate adaptation finance and the realization of planning processes (including National Adaptation Plans) within some of these highly vulnerable countries will inevitably affect (and be affected by) social and power relations, including relations between citizens and the state. Although Tanner and Allouche (2011, p. 1) state that there is still a "frequent assumption of linear policymaking and apolitical, techno-managerial solutions to the climate change challenge", a long-established literature on environmental issues and development (Adams, 2008; Blaikie \& Brookfield, 1987; Bryant \& Bailey, 1997; Forsyth, 2002; Keeley \& Scoones, 2000) confirms that local interactions both to protect resources and to

\footnotetext{
*Corresponding author. Email: david.dodman@iied.org
} 
adapt to adverse changes in environmental goods and services are highly political.

Politics, as elaborated by Leftwich (2008, p. 5), is clearly essential for decision-making related to climate change: "If it is to survive and prosper, any human community - whether a family or a federation - must have a means for making binding collective decisions: that means is its politics." Unless critical decisions are made and implemented, climate change will not be addressed. Both governments and civil society actors are actively engaged in working out both the specificities of climate change policy and programmes, and more generally how societies might form binding agreements on what needs to be done that are acted on. However, climate change policy does not take place in isolation. Indeed, in Zimbabwe, we recognize that decisions related to resource acquisition and use are highly contested, with differences frequently resolved by violence. Foucault's suggestion that "politics is war continued by other means" (Dean, 1999 , p. 25) is therefore relevant, in that it highlights the importance of nurturing political processes as a means for dealing with contestation. More generally, there has been a broad failure by development scholars and practitioners to understand national political contexts and to pay attention to political relations and political outcomes (Hickey \& Bracking, 2005), with significant implications for the effectiveness of development interventions, particularly their ability to reach marginalized or otherwise vulnerable groups. This is not only important because of a failure to act and analyse politically, but also because all indications are that political capability is not fixed but emerges through practice.

The central purpose of this paper is to examine the way in which the discourse and practice of "climate change" has been incorporated in, and has the potential to influence, national politics in a context marked by high levels of political contestation (Zimbabwe). We believe (along with Lockwood, 2013) that a neglect of these considerations will weaken the ability of interventions aimed at reducing vulnerability to result in meaningful long-term change and that taking them on board will enable adaptation activities to achieve broader development and governance benefits. At the same time, we recognize that the absence of a stable governance regime appears not to be a barrier to the implementation of adaptation planning and action: Bangladesh, Nepal, and the Maldives are all countries well known for their activities in this area during periods of political uncertainty (Alam et al., 2011; Ayers, Kaur, \& Anderson, 2011; Kothari, 2013). However, we argue that understanding the way in which climate change adaptation functions within contested political spaces is vital to strengthening policy and action in this area that meets the needs of highly vulnerable groups.

Our argument is that local and national politics matter greatly: both in terms of how climate change is incorporated into national policies and programmes and in terms of how climate change-related politics has an impact on broader political processes. In the cases cited above (with the notable exception of Kothari's research in the Maldives), national political dynamics have been treated relatively uncritically by climate change-related commentators and academic researchers. ${ }^{1}$ Indeed, consistent with Hickey and Bracking (2005), recent work has argued that climate change adaptation in vulnerable countries operates within an intentionally depoliticized space (Kelman, 2013), and that this may lead to the perpetuation of political systems that may result in long-term maladaptation (Lockwood, 2013). The examination of these dynamics in Zimbabwe - a country with widely recognized challenges of governance and politics - can help to illustrate some of the opportunities for addressing the consequences of climate change and facilitating its incorporation into a national political agenda even in conditions that may be seen as unfavourable. Simultaneously, however, it can highlight the threats that an uncritical support for governments in this realm of activity may have for broader developmental goals, particularly those that affect low-income and marginalized rural and urban populations.

The next section of this paper describes the context in which this investigation has been undertaken. This includes the governance, development, and climate-related situation of Zimbabwe; and also an overview of the complicated research terrain around issues of development, environment, and climate change policy. The first question addressed by this paper - what is the way in which climate change (in terms of both discourse and practice) has been incorporated into Zimbabwean politics and policies? - is answered in Section 3 through an examination of four key factors: the way in which the environment and climate change issues are framed by key actors, the national political context, partnerships between civil society and the government, and global climate change policies. The fourth section explores the implications of this process for broader political processes and relations and argues that politicians and practitioners alike need to engage with several fundamental questions if adaptation is to generate sustainable long-term improvements in the living conditions for citizens in low-income nations.

The research was informed by our prior engagement with issues of urban poverty, urban development, and climate change adaptation in various contexts (Dodman \& Mitlin 2013; Dodman, Mitlin, \& Rayos Co, 2010) which suggested the importance of engaging with local politics and power relations informing the intersection of these issues. It also builds on our previous work on housing and shelter (Mitlin, 2004; Mitlin \& Chitekwe, 2001), and climate change (Brown et al., 2013) in Zimbabwe which has highlighted the need to examine the relationship between citizens, civil society, and the state as a means of 
understanding and influencing more effective and pro-poor policy responses in these areas. The research presented in this paper builds on these experiences and was supplemented by 11 specifically targeted semi-structured interviews held between February and April 2013, as well as several other less formalized discussions. Because of the generally sensitive nature of Zimbabwean politics and political appointments, the individual interviewees have not been named, but they include a senior government minister in the Government of National Unity (GNU) (that was in power from 2009 to 2013); senior civil servants responsible for issues of water, agriculture, and climate change; NGO officials; representatives from UN agencies; NGO staff; and academics. Topics for these discussions included the basis for engaging with climate change in Zimbabwe; the relationship between climate change and multiple stressors affecting the country; and the roles of and relationships between civil society, local government, and national government in responding to climate change.

\section{Climate change in Zimbabwe: the environment, development, and research contexts Vulnerability to climate change in Zimbabwe}

Vulnerability to climate change is usually understood as a characteristic shaped by exposure to a particular climate change-related hazard and the level of sensitivity and adaptive capacity of the exposed system (IPCC, 2007). Huq and Ayers (2007) identify Small Island Developing States, Least Developed Countries (LDCs), and all of Africa as the 100 "most vulnerable" countries that are most likely to be severely affected by climate change, and that simultaneously bear very little responsibility for historic or present-day greenhouse gas emissions that cause this; Füssel (2010) confirms the inequity between national responsibility for emissions and the vulnerability of food security, human health and coastal populations; while Zimbabwe itself has long been identified as vulnerable to climate change (Bohle, Downing, \& Watts, 1994).
Exposure to future changes in the climate is one of the factors contributing to a more general vulnerability. Climate change projections are limited in Zimbabwe but are available for Rusape (a town about $170 \mathrm{~km}$ south-east of Harare) - and these demonstrate both the potential risks and the uncertainties associated with the present state of knowledge. A range of scenarios have been produced for two different Representative Concentration Pathways (van Vuuren et al., 2011), all of which show a clear rise in temperature by the period 2040-2060 although predictions about the actual extent of this lack precision (it could be a less than $1^{\circ} \mathrm{C}$ increase in some months, or a more than $4^{\circ} \mathrm{C}$ increase in others). Changes in future rainfall are even less clear with possibilities of both decreases and increases. This lack of certainty makes it difficult to identify and implement particular interventions and makes it more important to develop responses that are appropriate for a wide range of possible climatic situations (Carmin \& Dodman, 2013).

More recently, Zimbabwe's Second National Communication to the UNFCCC (Ministry of Environment and Natural Resources Management, 2012) identifies the main impacts of and vulnerability to climate change as existing in the sectors of agriculture, biodiversity, rangeland, water, health, and human settlement and tourism indicating the main priority areas currently identified by the government (Table 1). This table is not presented as an uncritical and objective listing, but rather as an indication of the priority areas currently identified by the government. The Second National Communication is the most comprehensive review of the anticipated impacts of climate change in the country, while various NGO and other reports (Brown et al., 2013) have also identified the risks facing sectors such as agriculture, livelihoods, and water resources. The relatively low prioritization given to human settlements is notably problematic, given the rapid urbanization that has been taking place in recent years the proportion of the population living in urban areas has grown from $10.6 \%$ in 1950 to $22.4 \%$ in 1980 and $38.1 \%$ in 2010 , and is expected to increase further to $46.2 \%$ in

Table 1. Impacts, vulnerability, and adaptation to climate change in Zimbabwe.

\begin{tabular}{ll}
\hline Sector & Explanation \\
\hline Agriculture & $\begin{array}{c}\text { Vulnerability and adaptation assessed using three indicator crops (sorghum, maize, and cotton): area suitable } \\
\text { for maize and cotton will decrease in northern and southern parts of the country; sorghum shows less } \\
\text { sensitivity to climate change } \\
\text { Plant diversity and ecosystem function are expected to decline as a result of increasing temperatures and } \\
\text { decreasing rainfall } \\
\text { Biodiversity }\end{array}$ \\
$\begin{array}{l}\text { Net primary productivity of rangelands is likely to decrease } \\
\text { Rangeland } \\
\text { Water }\end{array}$ & $\begin{array}{c}\text { Malaria selected as an indicator disease closely related to climate: high malaria hazard expected to be } \\
\text { concentrated in low-lying areas including Zambezi Valley and south-east lowveld } \\
\text { Health }\end{array}$ \\
$\begin{array}{c}\text { Expected to be affected by negative effects of climate change on agriculture, health, water resources, } \\
\text { Human settlement and } \\
\text { tourism }\end{array}$ & rangelands, biodiversity, and agro-ecological regions \\
\hline
\end{tabular}

Source: Ministry of Environment and Natural Resources Management (2012). 
2025 (UN DESA, 2012). In addition, the anticipated impacts and vulnerability take no account of urban residents living in poorly serviced over-crowded low-income and informal settlements, or any potential effects on urban networked infrastructure (including buildings, roads, electricity generation and distribution networks, water supply and drainage networks, or telecommunications networks). This marginalization is in itself highly politicized and reflects the prevailing governmental attitude throughout much of Africa that urbanization is a negative process to be avoided through effective rural climate and development policy (Pieterse, 2010). However, while various authors have identified deliberate acts of retribution against urban voters in Zimbabwe in the period following the 2005 presidential election (Bratton, 2011), this was not directly raised as a factor to explain the relatively marginal treatment of towns and cities in climate change response strategies.

\section{The development and governance context in Zimbabwe}

In addition to exposure to changes in climate, the other major drivers of vulnerability to climate change are sensitivity (the potential of a system to be adversely affected) and adaptive capacity (the potential of a system to adapt). At the national scale, these are clearly shaped by the overall social, political, and economic situation. Recent decades have been particularly difficult for Zimbabwe. Although not officially classified as a LDC, its overall development and governance context clearly contribute to its vulnerability to climate change - its Human Development Index of 0.397 (lower than the sub-Saharan African average of 0.475 ) falls in the level categorized as "low human development", and positions the country at 172 in the world by this index (UNDP, 2012), while 72\% of Zimbabweans lived in poverty and $22 \%$ in extreme poverty in 2011 (Zimstat, 2013, p. 44). A key catalyst for the economic difficulties faced in this recent period was the spontaneous and then regularized (through the Fast Track Land Reform Programme) land invasions. In addition, mismanagement of the economy from 2003 onwards resulted in accelerating inflation which reached an annual rate of 231 million per cent in July 2008 (Central Statistical Office quoted in Chimhowu, 2009, p. 20).

In 2009, following a disputed election in 2008, a negotiated settlement resulted in a new GNU taking up office with ZANU-PF and Movement for Democratic Change (MDC) politicians sharing posts in the Cabinet. This government "dollarized" the economy to control inflation: economic growth gradually returned and GDP is estimated to have increased from $\$ 6.1$ million in 2009 to US\$7.4 million in 2011 (in constant 2009 prices), with per capita GDP increasing from $\$ 501$ to $\$ 573$ over the same period (Zimstat, 2013, pp. 9-10). However, there remains a considerable inability of the government to support the local population in many aspects of their well-being including access to basic services.

Although some scholars have recently argued that understanding climate change demands a more nuanced understanding of politics and power relations (Arnall, 2013; Marino \& Ribot, 2012), this has yet to filter down to analysis of these relations within the process of governance in the global South. However, there are exceptions Felli and Castree (2012, p. 4) criticize the UK Government Foresight Report on Migration and Global Environmental Change for failing to discuss the conditions under which "poor people could actually use their representative state bodies in order to implement suitable adaptive measures - for instance, developmental policies, welfare provision, redistributive social protection, and infrastructural investments". We recognize the importance of such analyses and, in response to this, the following sections engage with the key discourses and practices that shape the way in which climate change is incorporated within government and policy frameworks in Zimbabwe in part due to pressure from organized citizens. As will be seen, these can include both working within the policy spaces and opportunities of the existing governance regime, and actively seeking to shape these in a way that supports broader resilience or transformation. This is based on a premise that more meaningful involvement of low-income groups in decision-making is essential to improving their lives and well-being (Mitlin \& Satterthwaite, 2013; Satterthwaite \& Mitlin, 2014) - a statement supported by ample empirical evidence in relation to local-level climate adaptation projects (Ensor \& Berger, 2009; Reid, Ampomah, Olazábal Prera, Rabbani, \& Zvigadza, 2012; Reid et al., 2009).

\section{Incorporating climate change in Zimbabwe's national politics}

Despite facing a range of political, social, economic, and environmental challenges, many individuals, organizations, and agencies in Zimbabwe have become actively engaged in addressing the consequences of climate change. The country produced its Initial National Communication to the UNFCCC in 1998 and its Second National Communication in 2013; a National Climate Change Response Strategy is currently under preparation (Zvigadza \& Madumira, 2012). ${ }^{2}$ There is also active civil society involvement on the issue: the Zimbabwe Climate Change Working Group has more than 30 civil society organizations as members and meets regularly; and the Zimbabwe climate change youth network coalition was formed in 2009 "with a view to raising youth awareness on climate change and enhancing their participation in national, regional and international climate change agendas" (Reid et al., 2012, p. 18). More broadly, information on climate change appears regularly in the print and broadcast media. 
In a context of continuing political contestation and considerable development needs, it is not immediately obvious why climate change has been an issue for government or civil society. This section explores four main factors that might help to explain this broad incorporation of climate change in national discourses and politics in Zimbabwe: the framing of weather and climate as a central part of national life; the emergence of governance structures that address climate change; the evolution of partnerships between civil society and the state; and the role of international climate change initiatives.

\section{Framings of the environment and climate change}

Framing can be understood as "the process by which issues, decisions, or events acquire different meanings from different perspectives" (Dewulf, 2013, p. 322), while frames can be conceived of as "organizing principles that enable a particular interpretation of a phenomenon" (de Boer, Wardekker, \& van der Sluijs, 2010, p. 502). Such framings help to give meaning to particular phenomenon and involve associations related to that phenomenon. The way in which environmental and climate change issues are framed therefore shapes the ways in which people respond to them, and provides an underlying basis for understanding how such issues fit within social and power relations. Dominant frames and narratives can both reflect the priorities of more powerful groups and can be used to support the actions that these groups wish to take - as documented for the case of planned resettlement in the Lower Zambezi River valley by Arnall (2013). When frames are made more explicit, this can disturb taken-for-granted assumptions and can contribute to the disruption of established norms. This appears to have happened in the case of urban sanitation, as increasing water shortages have demonstrated the redundancy of water-borne systems and some municipalities have responded positively to the demands of the organized urban poor that eco-sanitation options be permitted within local authority regulations (Dialogue on Shelter, 2014).

Despite growing levels of urbanization, Zimbabwe remains a country in which even urban dwellers consider themselves to have a rural home. This forms one frame for issues of climate change: almost all interviewees identified the high proportion of Zimbabweans reliant on agriculture for livelihoods; almost all stated that "people in communities" (generally referring to rural agricultural communities) recognize changing patterns of rainfall and seasons; and almost all recognized the relationship between climate change (including changing seasonal patterns) and food security (both for rural communities and for the country as a whole). Many government and NGO officials also suggest that the country as a whole is conscious of environmental and climate change issues because of the influence of changing patterns of rainfall on agricultural productivity. The recent economic crisis has reinforced this understanding as increasing numbers of urban residents sought to return temporarily to and/or secure food supplies from rural areas to help them manage rapid inflation and falling incomes.

In addition, climate change in Zimbabwe needs to be seen against the backdrop of long-standing political tensions over environmental issues in different forms, going back to the colonial period. There is a history of environmental actions being imposed by the colonial government, for example, the forced construction of contour ridges to prevent soil erosion (Marongwe, 2002). The controversial (and complicated) land reform process can also be partially interpreted as an example of a contest over natural resources. It also needs to be seen alongside changing demographic patterns, including the movement of people into the "frontier" - which means that increased exposure to climatic hazards can be a result of changing location of people as well as changing intensity of hazards. The "threat" of climate change is therefore frequently framed as a threat to agricultural productivity and food security, and as being strongly linked to national identity and well-being (as a food-producing nation, despite substantial challenges in this regard in recent decades). This framing can help to explain why politicians and citizens alike see climate change as a central issue for the nation, and why it is accorded relatively high levels of political status.

\section{Governance structures for climate change in Zimbabwe}

The governance structure for climate change in Zimbabwe is composed of the following elements:

- National Climate Change Office. This office is based in the Ministry of Environment and is funded by the UNDP. It has responsibility for engaging with UNFCCC and for producing the National Communications.

- National Climate Change Task Team. This team is coordinated by the Office of the President and Cabinet (OPC) with a dedicated Permanent Secretary and receives a small budget allocation from the central government. The members of the task team are the Permanent Secretaries from relevant ministries (environment, water, agriculture, and economic planning). This body is responsible for producing the National Climate Change Response Strategy (and, subsequently, the National Climate Change Plan) according to the timeline indicated in the Zimbabwe Medium Term Plan (2011-2015).

- National Climate Change Steering Committee. This body has a wider range of participants from government and civil society and is intended to guide the production of the National Climate Change Response Strategy. 
These systems for managing climate change have evolved in a way that suggests the issue is indeed seen as a priority. This has involved centralized coordination, with the creation of a National Task Team under the OPC. A similar approach has been used for other cross-cutting issues including the implementation of the Millennium Development Goals, responses to corruption, the introduction of Information and Communications Technology in schools, and the structuring of the UN Development Assistance Framework. Observations on the efficacy of this approach were mixed: with some interviewees being generally in favour of this type of coordination, explaining that activities managed by the OPC are treated with greater priority by other ministries, and that the OPC has a stronger "power to convene" than individual line ministries (particularly the Ministry of Environment). Others felt that the actual successes of this body were much more limited. The process of developing the National Climate Change Response Strategy has been consultative, with meetings in Nyanga, Bulawayo, and Harare, although there has been no assessment of whether this has incorporated meaningful engagement with low-income and vulnerable groups - who themselves face a range of pressing issues related to daily survival that quite reasonably curtail their involvement in these types of activities.

The centralization of responsibility for climate change has also marginalized some previously powerful actors in the field. There appear to be some residual tensions from ministries and agencies that previously had substantial influence on climate change. Some identified a cluster of ministries organized around the "environment" (environment, water, and agriculture) and a cluster organized around the "economy" (economic planning, finance, and small and medium enterprises), each of which had competing claims for priority in engaging with issues of the climate and natural resources. The National Climate Change Office is based in the Ministry of Environment and Tourism and is funded entirely by the UNDP as part of a three year, US\$8.3 million project to strengthen national capacity for climate change mitigation and adaptation. ${ }^{3}$ This office is the national focal point for engagement with the UN Framework Convention on Climate Change and is responsible for producing National Communications to the UNFCCC. One interpretation of the reason for locating the Climate Change Office in this ministry is the recognition of the need for technical expertise in the area. But some interviewees felt that the presence of externally funded "projects" in ministries could lead to tensions with other less-well-resourced departments.

Yet despite some of these organizational changes to address climate change concerns, there has only been very limited allocation of resources by the government to address the issue. The financial constraints facing the Government of Zimbabwe are frequently referred to, particularly the extremely limited budget available for anything other than recurrent expenditure (particularly civil service salaries). ${ }^{4}$ This may be a significant factor preventing government spending on climate change activities and may also be impeding more meaningful cross-sectoral linkages being realized. Climate change can be seen as a relevant issue in planning for future energy generation, in implementing water, sanitation, and hygiene projects, and in understanding the distribution of disease vectors. But in contrast to many other countries (and perhaps because of the limited funding available) - climate change is not being used as an entry point to engage with (or even access international funds for) these other priority areas. There are exceptions, notably in the water sector - where climate change is clearly defined both as a stressor to water availability and also as a reason to implement particular projects (particularly around hydro-meteorological monitoring and early warning systems). In addition, the Africa Ministerial Council on Water (AMCOW) has just commenced funding activities on "water, climate, and development" that will address issues of awareness, rainwater harvesting, and small dams.

The policies and organizational structures around climate change must also be seen against the backdrop of present governance arrangements and tensions. Government officials and ministers state the importance of climate change, and it is frequently and increasingly covered in the print and electronic media. While many issues of government policy were disputed during the period of the GNU (2008-2013) between ministries led by representatives from the two main parties, climate change appeared to be less disputed than many other topics. Indeed, it was suggested that environmental issues in general were recognized to be of public importance and that Zimbabwean as citizens have a deep respect for the natural world that results in something of a political consensus. An interviewee at ministerial level stated that climate change is not just a responsibility for northern countries, but requires action on both mitigation and adaptation in the south - including in Zimbabwe. At the same time, however, many other issues were clamouring for politicians' and civil servants' attention - not only the economy, but also the rule of law, the creation of the new constitution, and (at the time of the interviews) the holding of the 2013 election.

\section{Evolving partnerships between government and civil society}

"Partnership models" are increasingly accepted as being essential components of effective climate change adaptation in low-income countries (Dyer et al., 2013; Forsyth, 2013), and a range of partnerships between civil society and the state can be observed in Zimbabwe. In general, there is substantial mistrust between civil society organizations and the government, particularly with 
organizations addressing issues such as human rights and the extractive industries: in contrast, however, there seem to be much stronger working relationships between civil society and the government around the topic of climate change.

Interviewees agreed that there is a very effective Civil Society Climate Change Working Group which provides a useful focal point for relationships between government and civil society, and which has helped to coordinate civil society engagement in the National Climate Change Steering Committee. Civil society is actively part of the national steering committee, providing background information and policy suggestions. There is recognition by government stakeholders that civil society organizations have been leading the process of engaging with communities around climate change, meaning that the relationship between civil society and government around climate change functions more effectively than this relationship on other issues. This is recognized on both sides: civil society organizations have "applauded progress" on the government's climate change response strategy (Zvigadza \& Madumira, 2012).

This cooperation is not unique to climate change: there is also much collaboration around the coproduction of basic services in many towns and cities that are facing a crisis in the provision of these. In both cases, it appears that positive relations are driven by functionality: without alternative sources of funds and with a need for new approaches, there is an increased interest in collaboration. Indeed, one government minister stated that "there is no ministry that does not work with civil society, although for some there is a rhetoric of distance". In the urban context, a somewhat different politics is playing out more generally. The model of state-led development that was supported by colonial practices and maintained by the independent state is evidently redundant. It requires resources (either from national government or from local corporate activity) and this is not happening. Consequently, local government (which is dominated in rural areas by ZANU-PF and in urban areas by the MDC) is more interested in partnership with civil society. On the one hand, they cannot make their past approach work - and hence have to be open to new approaches if they are to be credible. On the other, they are themselves resource starved and hence open to alliances that might address investment needs.

What might be driving these partnerships around climate change? Firstly, as described above there is some cross-sector recognition of the effects of climate change, particularly at the level of impacts on smallholder agriculture - and few would deny this or not want to address it. Secondly, there are many other issues that are seen as higher priorities and that are more contested - food security, the economy, job creation, and governance - which means that climate change is a relatively "safe" topic on which to demonstrate cooperation. Thirdly, there are limited resources allocated to climate change, including from international development partners (only UNDP is a significant actor) - meaning that there are not substantial funds to be struggled over.

\section{Global climate change priorities and policies}

Events and decisions at the global scale shape understandings of climate risk and ability to respond within national and local contexts. These can be formal, and include decisions made in the UNFCCC negotiations and the creation of particular institutional arrangements for financing climate change responses (e.g. the Green Climate Fund). However, there are also institutional and discursive links which mean that local responses to climate change cannot be isolated from global discussions (Olwig, 2012, p. 112; Rodima-Taylor, Olwig, \& Chhetri, 2012;) - actors in Africa have been shown to respond not only to changes in climate, but also to the "idea" of adaptation as promulgated by international actors (Weisser, Bollig, Doevenspeck, \& Muller-Mahn, 2013). Despite various international sanctions (largely against individual government officials), Zimbabwe and Zimbabweans are well connected in many international agendas, including those around climate change. Zimbabwe is an active participant in the UNFCCC, and many international NGOs with programmes on climate change are present in the country. In addition, the Zimbabwean media frequently report on climate change concerns based on information generated elsewhere in Africa and the rest of the world.

The recognition of climate change as an important issue in Zimbabwe has been partially shaped by these international discourses, including donor priorities. But apart from UNDP - the main bi-lateral and multi-lateral agencies are not engaged in projects or programmes for climate change adaptation in Zimbabwe. Although the resources allocated to climate change are almost entirely generated from outside the country, they are still very limited, as are the activities of donors in this area. Examples include the UNDP "Coping with Drought and Climate Change" project ${ }^{5}$ and some Global Environment Facility small grants (also managed by UNDP). Humanitarian/aid agencies have been more active, with a range of projects that take community-based approaches to adaptation, that seek to mainstream climate change adaptation and disaster risk reduction, and that aim to increase food and livelihood security in the context of climate change (see Brown et al., 2013, for further description of these examples).

\section{Climate change and its potential to influence national politics}

The preceding sections are based on empirical evidence showing how climate change has been included in the national political agenda. The following section poses 
three questions that remain unanswered, but that we believe are fundamental to understanding the broader political implications of work related to climate change in lowincome countries particularly those with political instability. These questions are related to the implications for state and citizen relations of an engagement through climate change; the potential for engagement with climate change to achieve transformational change; and the extent to which current efforts to respond to climate change are able to contribute to addressing broader political challenges. We raise these questions because we think that the issues they raise have the potential to be significant and because we think that there is some evidence that each of them is happening. More importantly, however, we argue that further attention needs to be paid to these questions by researchers, by climate change and development practitioners, and by politicians and state officials if climate change adaptation is to generate sustainable longterm improvements in livelihoods and well-being for citizens in these contexts.

\section{Does the attention to climate change contribute to re-shaping relationships between citizens and the (local and national) state through an understanding and practice of comparative advantage?}

Firstly, it is worth examining whether the patterns of engagement around climate change could indicate new ways of working between civil society and the state in other areas that contribute to human development and well-being. While partnerships between different stakeholders are widely recognized as being important for effective implementation of climate change adaptation projects (Adhikari \& Taylor, 2012; Dyer et al., 2013), the lasting implications of these for citizen-state relations are rarely questioned in climate change literature. At the moment, civil society actors working on climate change function in a relatively strong position in Zimbabwe - they have the ability to generate knowledge and information about climate risks and responses, they can draw on resources to implement projects and programmes around climate change adaptation, and they are well integrated in global networks (with substantial Zimbabwean civil society participation at the UNFCCC Conferences of Parties and other international meetings). In contrast, the state lacks many of these resources - so has had to rely on partnerships with civil society to demonstrate progress.

The relative weakness of the state therefore means that the state and civil society can operate in closer partnership than might otherwise be the case - but may suggest that the issue of climate change itself has been "depoliticized" (Arnall, Kothari, \& Kelman, 2013; Kelman, 2013). As described above, there is some evidence that climate change is functioning in this way at this moment in time although it might be the case that it is political but not openly contentious. We argue that there is recognition among all agencies that such choices are political and involve an awareness of both the need for and difficulties of collective decision-making. As we report above, there are new forms of relationship between civil society and the state emerging based on an understanding of sectoral comparative advantage. However, it is not yet clear that the state has come to understand that despite its apparent power, social and cultural change can be instigated through voluntary organizations and their associations in ways that the state itself cannot easily replicate. A related and critical question to ask is if more resources become available, will these lessons be embedded or will there between competition between state and civil society organizations? And if this is the case, how should the providers of resources proceed? At the moment, it is not clear that such lessons and associated lessons are embedded, and resource providers should proceed with caution. While foundations are in place, it is not evident that they will necessarily be built on successfully.

\section{Can the attention given to climate change by the state- and by the state in partnership with civil society - be seen as "transformative"?}

There is growing discussion about the different outcomes that can arise from adaptation activities, and whether these contribute simply to "coping" with difficult circumstances or contribute to more "transformative" change that reduces long-term vulnerability to a wide range of shocks and stresses (including, but not limited to, those related to climate change) (Kates, Travis, \& Wilbanks, 2012; O'Brien, 2012; Pelling, 2010). Moser and Boykoff (2013, 14) explain "successful adaptation" as operating along a continuum from "maladaptation" to "building something different or better" (p. 14), while Dow, Berkhout, and Preston (2013) highlight the need for "transformative" approaches when financial, social, politi$\mathrm{cal}$, technological, or cultural limits to more standard adaptation approaches are met. Zimbabwe is in an ongoing state of political and social change. While the new constitution was adopted in March 2013, the national elections in July 2013 consolidated the position of ZANU-PF in government. While many changes can be observed, it is too early to suggest whether these are transformative in nature - indeed they appear to be in considerable flux and as yet, state engagement in climate change issues is insufficient to have had this type of wide-ranging impact on relationships between the state, citizens, and civil society.

This paper points to two different but related questions pertaining to transformation. Firstly, it highlights the importance of enquiring whether activities undertaken (either by civil society or state actors) with the purpose of climate change adaptation lead to socially and 
environmentally just outcomes. In many ways, this is a question of due process and "best practice", in ensuring that the necessary checks and balances are in place to ensure that the consequences of these activities benefit marginalized or particularly vulnerable groups (including awareness of gender, age, disability, and poverty). But there is a second, more political question - do these actions contribute to progress in moving towards a more equitable society in which the underlying drivers of vulnerability (both within and beyond changes in the climate) are addressed, thereby contributing to broader social progress as well as reduced susceptibility to climate-related hazards? In other words, does engagement with climate change build institutional practices that offer broader application to other development challenges and that build a consciousness that is likely to lead to broader transformations?

\section{Is the engagement with climate change able to address the necessarily difficult political issues?}

As described above, there is a long-standing recognition of the importance of the environment in Zimbabwe: both for its functional role as a central pillar of the national economy and for its semiotic role as a component of national cultural identity. However, in a political system with considerable levels of mistrust, it is possible that climate change simply plays a convenient role as an issue around which collaboration and cooperation can be practised - because the delicate (and frequently disrupted) balance of society requires the presence of issues of this type to "hold things together". So many other issues in Zimbabwe are highly contested that there is a value for both government and civil society agencies alike to have areas in which they can demonstrate and practice cooperation - without these, the social compact between citizens, civil society, and the state would be even more tenuous than it is at present and a range of day-to-day tasks would be more difficult. To an extent, climate change seems to be one area in which this type of partnership can be observed.

In addition to politicians recognizing the immediate functionality of practising engagement with their political competitors around particular issues, it may be that working together on these types of "consensus" issues increases their own personal political legitimacy. For civil society agencies, the context has been exceptionally difficult with imprisonment and informal (often violent) coercion. Bratton's (2011) report on a survey of citizen views on peace, violence, and transitional justice in Zimbabwe highlights the priority given to peace and to legal solutions, despite a very considerable exposure to violence, and suggests that it is in the self-interest of politicians to invest in these activities. Are civil society agencies investing in climate change in part because it offers them a chance to build relations with the state and reduce operational risks? In that regard, it is worth continuing to ask whether the apparent commitment to engaging with climate change is really substantive - or whether it is simply fulfilling a necessary political function that could potentially be transposed to a different issue. If this is the case then careful consideration needs to be given to the implications for increased action on climate change that will be contentious (as there will be winners and losers), and hence not associated with consensus building and collaboration that underpins current efforts. However, it is also possible to look more positively on these efforts. If we draw on our earlier discussion to consider politics as an alternative to violence and war, then the significance of these engagements is clearer and we can recognize that "depoliticized" activities may be intensely political despite not being contentious. Indeed, we need to differentiate between those activities that are technical (i.e. not concerned with politics) and those that involve political relations albeit without explicit contestation. In the case of the latter, we recognize that the capability to negotiate and compromise across group needs and interests is built through such activities, and demonstrated success is likely to build both capacity and commitment for political action within both state and civil society. Hence even if addressing climate change is not secured through these engagements in the short and medium term, they help to build an agenda for a more peaceful future because they build a repertoire of ways of acting that are political.

\section{Conclusion: politics matters in multiple ways}

The growing global importance ascribed to climate change and the expanding policy framework for addressing it have shaped national discourses and institutions in a wide range of vulnerable countries - including Zimbabwe. These include the creation of formal sections within governments (like the National Climate Change Office and Task Team in Zimbabwe) and the production of official documentation (such as the National Communications to the UNFCCC). Simultaneously, growing engagement in this area by international NGOs and donors has shaped the local civil society context, with new resources (knowledge, finances, and networks) becoming available resulting in increased programming in this area. This paper suggests that these two processes currently exist in a state of dynamic tension in Zimbabwe - and that understanding and engaging with the local political context is essential if the outcomes of this tension are to result in substantial improvements in the resilience and well-being of citizens.

The paper also highlights the need for further political economy analysis of climate change responses in Zimbabwe. Elements of this highlighted by Tanner and Allouche (2011) include the role of ideology, actors, and 
power relations in the policy process; the role of scarcity and poverty in mediating completing claims for resources; and the influence of ideology, incentives, and power relations in decision-making. At present, these issues are understood in a relatively unproblematic manner, with a tacit expectation that partnerships between civil society and the state will lead to the creation of sound policies that will result in positive outcomes. But evidence from past contests over natural resources suggests that this is rarely the case.

Much of the existing theoretical reflection about the power relations around climate change has been based on mitigation policies at a global level. Little has engaged with empirical observation of policy processes in low-income countries. Yet climate change is going to shape patterns of aid and priorities for development in a range of low-income nations like Zimbabwe, and the ways in which this is affected by and is likely to shape national politics need to be better understood. The way it is managed will have implications both directly for the efficacy of programme design and its effect on building resilience in the most vulnerable groups. And it will also have implications for the nature of democracy, the relationship between the local and national state, and the relationship between citizens and the state. The implications of current relationships between state and civil society are not clear and are unlikely to be clear in the short term but equally are critical to effective action.

Climate change policy and programming have provided a useful meeting point for civil society and government agencies. But it remains to be seen how this will develop. While these relations may still be in - and may never progress beyond - their initial stages, and there is uncertainty about the scale and nature of future collaborative interventions, the interactive practices required for working together are being developed and strengthened. These practices open up new options for politics in Zimbabwe that are relevant both to effective responses to climate change and other development goals.

\section{Acknowledgements}

This research was funded by UK aid from the Department for International Development. Its conclusions do not necessarily reflect the views of the UK Government.

\section{Notes}

1. Of course, the significance of politics is not unique to the contexts of natural resource management or climate change: Bratton (2011) shows how engaging with national politics is essential for understanding the contrasting approaches to peace and justice following Zimbabwe's violent presidential election campaign of 2008 .

2. A consultation draft of this document is available at http:// www.ies.ac.zw/downloads/draft $\% 20$ strategy.pdf.
3. http://www.undp.org.zw/component/content/article/21-envir onment-energy-news/225-supporting-national-capacity-for-a daptation-and-mitigation-to-climate-change.

4. In January 2013, The Guardian (UK) reported that Zimbabwe's national bank balance stood at only US\$217 (http://www.theguardian.com/world/2013/jan/30/zimbabwe an-government-bank-balance-down?INTCMP=SRCH).

5. See http://www.undp.org.zw/focus-areas/environment-ener gy/coping-with-drought-and-climate-change.

\section{References}

Adams, W. (2008). Green development: Environment and sustainability in a developing world (3rd ed.). London: Routledge.

Adhikari, B., \& Taylor, K. (2012). Vulnerability and adaptation to climate change: A review of local actions and national policy response. Climate and Development, 4(1), 54-65.

Alam, K., Shamsuddoha, M., Tanner, T., Sultana, M., Huq, M., \& Kabir, S. (2011). The political economy of climate resilient development planning in Bangladesh. IDS Bulletin, 42(3), $52-61$.

Arnall, A. (2013). A climate of control: Flooding, displacement and planned resettlement in the Lower Zambezi River valley, Mozambique. The Geographical Journal, early online edition. doi:10.1111/geoj.12036

Arnall, A., Kothari, U., \& Kelman, I. (2013). Introduction to politics of climate change: Discourses of policy and practice in developing countries. The Geographical Journal, early online edition. doi:10.1111/geoj.12054

Ayers, J., Kaur, N., \& Anderson, S. (2011). Negotiating climate resilience in Nepal. IDS Bulletin, 42(3), 70-79.

Betsill, M., \& Bulkeley, H. (2006). Cities and the multilevel governance of global climate change. Global Governance: A Review of Multilateralism and International Organizations, 12(2), 141-159.

Birkmann, J., Garschagen, M., Kraas, F., \& Quang, N. (2010). Adaptive urban governance: New challenges for the second generation of urban adaptation strategies to climate change. Sustainability Science, 5, 185-206.

Blaikie, P., \& Brookfield, H. (1987). Land degradation and society. London: Methuen.

de Boer, J., Wardekker, J., \& van der Sluijs, J. (2010). Framebased guide to situated decision-making on climate change. Global Environmental Change, 20, 502-510.

Bohle, H., Downing, T., \& Watts, M. (1994). Climate change and social vulnerability: Toward a sociology and geography of food insecurity. Global Environmental Change, 4(1), 37-48.

Bratton, M. (2011). Violence, partisanship and transitional justice in Zimbabwe. Journal of Modern African Studies, 49(3), 353380 .

Brown, D., Chanakira, R., Chatiza, K., Dhiliwayo, M., Dodman, D., Masiiwa, M., ... Zvigadza, S. (2013). Climate change impacts, vulnerability and adaptation in Zimbabwe. International Institute for Environment and Development, Climate Change Working Paper Number 3.

Bryant, R., \& Bailey, S. (1997). Third world political ecology. London: Routledge.

Bulkeley, H., \& Betsill, M. (2005). Rethinking sustainable cities: Multilevel governance and the 'urban' politics of climate change. Environmental Politics, 14(1), 42-63.

Carmin, J., \& Dodman, D. (2013). Engaging science and managing scientific uncertainty in urban climate adaptation planning. In S. Moser \& M. Boykoff (Eds.), Successful adaptation to climate change: Linking science and policy in a rapidly changing world (pp. 220-234). London: Routledge. 
Chimhowu, A. (2009). Moving forward in Zimbabwe: Reducing poverty and promoting growth. Manchester: Brooks World Poverty Institute.

Dean, M. (1999). Governmentality: Power and rule in modern society. London: Sage Publications.

Dewulf, A. (2013). Contrasting frames in policy debates on climate change adaptation. WIREs Climate Change, 4, 321-330.

Dialogue on Shelter. (2014). Chinhoyi situational analysis. London: SHARE.

Dodman, D., \& Mitlin, D. (2013). Challenges for communitybased adaptation: Discovering the potential for transformation. Journal of International Development, 25(5), 640-659.

Dodman, D., Mitlin, D., \& Rayos Co, J. (2010). Victims to victors, disasters to opportunities: Community-driven responses to climate change in the Philippines. International Development Planning Review, 32(1), 1-26.

Dow, K., Berkhout, F., \& Preston, B. (2013). Limits to adaptation to climate change: A risk approach. Current Opinion in Environmental Sustainability. Retrieved from http://dx.doi. org/10.1016/j.cosust.2013.07.005

Dyer, J., Leventon, J., Stringer, L., Dougill, A., Syampungani, S., Nshimi, M., ... Kafwifwi, A. (2013). Partnership models for climate compatible development: Experiences from Zambia. Resources, 2, 1-25.

Ensor, J., \& Berger, R. (2009). Understanding climate change adaptation: Lessons from community-based approaches. Rugby: Practical Action Publishing.

Felli, R., \& Castree, N. (2012). 'Neoliberalising adaptation to environmental change: Foresight or foreclosure' (commentary). Environment and Planning A, 44, 1-4.

Forsyth, T. (2002). Critical political ecology: The politics of environmental science. London: Routledge.

Forsyth, T. (2013). Community-based adaptation: A review of past and future challenges. WIREs Climate Change. doi:10. $1002 /$ wcc. 231

Füssel, H. (2010). How inequitable is the global distribution of responsibility, capability, and vulnerability to climate change: A comprehensive indicator-based assessment. Global Environmental Change, 20(4), 597-611.

Gasper, D., Portocarrero, A., \& St.Clair, A. (2013). The framing of climate change and development: A comparative analysis of the human development report 2007/8 and the world development report 2010. Global Environmental Change, 23, 28-39.

Hickey, S., \& Bracking, S. (2005). Exploring the politics of chronic poverty: From representation to a politics of justice? World Development, 33(6), 851-865.

Huq, S., \& Ayers, J. (2007). Critical list: The 100 nations most vulnerable to climate change. International Institute for Environment and Development, Sustainable Development Opinion. Retrieved from http://www.gm.undp.org/Reports/ $100 \% 20$ nations $\% 20$ most $\% 20$ vulnerable $\% 20$ to $\% 20$ climate $\%$ 20change.pdf

Intergovernmental Panel on Climate Change (IPCC). (2007). Contribution of working group II to the fourth assessment report of the intergovernmental panel on climate change. Cambridge: Cambridge University Press.

Kates, R., Travis, W., \& Wilbanks, T. (2012). Transformational adaptation when incremental adaptations to climate change are insufficient. Proceedings of the National Academy of Sciences, 109(19), 7156-7161.

Keeley, J., \& Scoones, I. (2000). Knowledge, power and politics: The environmental policy-making process in Ethiopia. The Journal of Modern African Studies, 38(1), 89-120.

Kehew, R., Kolisa, M., Rollo, C., Callejas, A., Alber, G., \& Ricci, L. (2013). Formulating and implementing climate change laws and policies in the Philippines, Mexico (Chiapas), and South Africa: A local government perspective. Local Environment, 18(6), 723-737.

Kelman, I. (2013). No change from climate change: Vulnerability and Small Island developing states. Geographical Journal, early online edition. doi:10.1111/geoj.12019

Kothari, U. (2013). Political discourses of climate change and migration: Resettlement policies in the Maldives. Geographical Journal, early online edition. doi:10.1111/ geoj.12032

Leftwich, A. (2008). Developmental states, effective states and poverty reduction: The primacy of politics. UNRISD Project on Poverty Reduction and Policy Regimes, Geneva, United Nations Research Institute for Social Development (UNRISD).

Lockwood, M. (2013). What can climate-adaptation policy in sub-Saharan Africa learn from research on governance and politics? Development Policy Review, 31(6), 647-676.

Marino, E., \& Ribot, J. (2012). Special issue introduction: Adding insult to injury: Climate change and the inequities of climate intervention. Global Environmental Change, 22, 323-328.

Marongwe, N. (2002). Conflicts over land and other natural resources in Zimbabwe. Harare: ZERO.

Ministry of Environment and Natural Resources Management. (2012). Zimbabwe second national communication to the United Nations Framework Convention on Climate Change. Harare: UNEP/Government of Zimbabwe/Global Environment Facility.

Mitlin, D. (2004). Securing voice and transforming practice in local government: The role of federating in grassroots development. In S. Hickey \& G. Mohan (Eds.), Participation: From tyranny to transformation? Exploring new approaches to participation (pp. 175-189). London: Zed Books.

Mitlin, D., \& Chitekwe, B. (2001). The urban poor under threat and in struggle: Options for urban development in Zimbabwe, 1995-2000. Environment and Urbanization, 13 (2), 85-101.

Mitlin, D., \& Satterthwaite, D. (2013). Urban poverty in the global south: Scale and nature. London: Routledge.

Moser, S., \& Boykoff, M. (2013). Climate change and adaptation success: The scope of the challenge. In S. Moser \& M. Boykoff (Eds.), Successful adaptation to climate change: Linking science and policy in a rapidly changing world (pp. 1-34). London: Routledge.

O'Brien, K. (2012). Global environmental change II: From adaptation to deliberate transformation. Progress in Human Geography, 36(5), 667-676.

Olwig, M. (2012). Multi-sited resilience: The mutual construction of 'local' and 'global' understandings and practices of adaptation and innovation. Applied Geography, 33, 112-118.

Pelling, M. (2010). Adaptation to climate change: From resilience to transformation. London: Routledge.

Pieterse, E. (2010). Filling the void: Towards an agenda for action on African urbanization. In E. Pieterse, (Ed.), Urbanization imperatives for Africa: Transcending policy inertia (pp. 727). South Africa: African Centre for Cities (ACC).

Reid, H., Alam, M., Berger, R., Cannon, T., Huq, S., \& Milligan, A. (2009). Community-based adaptation to climate change: An overview. Participatory Learning and Action, 60, 11-33.

Reid, H., Ampomah, G., Olazábal Prera, M., Rabbani, G., \& Zvigadza, S. (2012). Southern voices on climate policy choices: Analysis of and lessons learned from civil society advocacy on climate change. London: International Institute for Environment and Development. 
Roberts, D. (2008). Thinking globally, acting locally Institutionalizing climate change at the local government level in Durban, South Africa. Environment and Urbanization, 20 (2), 521-537.

Roberts, D. (2010). Prioritizing climate change adaptation and local level resilience in Durban, South Africa. Environment and Urbanization, 22(2), 397-413.

Rodima-Taylor, D., Olwig, M., \& Chhetri, N. (2012). Adaptation as innovation, innovation as adaptation: An institutional approach to climate change. Applied Geography, 33, 107-111.

Satterthwaite, D., \& Mitlin, D. (2014). Reducing urban poverty in the Global South. London: Routledge.

Tanner, T., \& Allouche, J. (2011). Towards a new political economy of climate change and development. IDS Bulletin, 42(3), 1-14.

Tanner, T., Mitchell, T., Polack, E., \& Guenther, B. (2009). Urban governance for adaptation: Assessing climate change resilience in Ten Asian Cities. Institute for Development Studies Working Paper 315 (January 2009).
United Nations Department of Economic and Social Affairs (UN-DESA). (2012). World urbanization prospects: The 2011 revision. Retrieved from http://esa.un.org/unpd/wup/index.htm

United Nations Development Programme (UNDP). (2012). International human development indicators (Zimbabwe). Retrieved from http://hdrstats.undp.org/en/countries/profiles/ ZWE.html

van Vuuren, D., Edmonds, J., Kainuma, M., Riahi, K., Thomson, A., Hibbard, K., ... Rose, S. (2011). The representative concentration pathways: An overview. Climatic Change, 109, 5-31.

Weisser, F., Bollig, M., Doevenspeck, M., \& Muller-Mahn, D. (2013). Translating the 'adaptation to climate change' paradigm: The politics of a travelling idea in Africa. Geographical Journal, early online edition. doi:10.1111/geoj.12037

Zimstat. (2013). Poverty and poverty datum line analysis in Zimbabwe. Harare: Zimbabwe National Statistics Agency.

Zvigadza, S., \& Madumira, W. (2012). CSOs applaud progress on climate change response strategy. Southern Voices. Retrieved from http://southernvoices.net/index.php?option=com_conte nt\&view $=$ article $\&$ id $=127 \&$ Itemid $=131$ 